\title{
“DESERVING” CHILDREN, “UNDESERVING” MOTHERS? MULTIPLE PERSPECTIVES ON THE CHILD SUPPORT GRANT
}

\section{Dorothee Hölscher, Madhu Kasiram, Reshma Sathiparsad}

\section{BACKGROUND TO THE STUDY}

Following the change from over 350 years of colonial and apartheid rule in South Africa, the first democratically elected government that came into power in 1994 was faced with the challenge of having to address vast levels of inequality and poverty. The distribution of wealth were extremely skewed in terms of race, gender and region, with children growing up in rural, black and female-headed households disproportionately affected by severe levels of poverty (Cassiem, Perry, Sadan \& Streak, 2000; Landman, Bhorat, Van der Berg \& Van Aardt, 2003; May, 1998; UNDP, 2004). Consequently, child mortality and levels of stunted growth in South Africa in general and amongst this group of children in particular were unacceptably high, and - by now constitutionally enshrined - children's rights and basic needs were unmet for the majority of South African children (Manuel, 2007). Poverty continues to be the biggest challenge faced by the government: Brandon and Pather (2007) for example cite that 24 million South Africans are living below the poverty line, half of whom are dependent on government grants.

One of the South African government's initiatives to address poverty in 1998 was the introduction of a R100 flat rate grant for children up to the age of seven years, payable to the child's care giver and subject to a means test. By the 2008/09 financial year, this amount was extended to R220 and the scope was broadened to include children up to the age of 15 (Manuel, 2008), reaching by now just under eight million beneficiaries. The Child Support Grant (CSG) replaced the previous State Maintenance Grant (SMG) which was biased towards "White", "Indian" and "Coloured" children and based on a contextually inappropriate nuclear family model (Lund, 2008; RSA, 1996). More importantly in view of large numbers of people who were previously excluded and now constitutionally entitled to access the SMG, that is, "Black" Africans from the former Bantustans and Homelands, extension of the grant was considered fiscally unsustainable.

The CSG's overarching rationale was one of achieving social justice (Barry, 2005; Ife \& Tesoriero, 2006), empowering women and families (Ife \& Tesoriero, 2006; Lee, 2001; Payne 2005), while at the same time being sensitive to the fluidity of South African family structures, especially in the poorest segments of society (Lund, 2008). Specifically, "the fact that in 1995, less than half of all African children under seven years old lived with both parents" (Budlender, in Lund, 2008:2) received attention in the conceptualisation of the grant. Thus, the grant's expressed intention was to alleviate poverty by retaining a cash benefit to the poor which was smaller but had a wider scope than the SMG. Designed to "follow the child" (Lund, 2008; RSA, 1996), thereby enabling the actual primary care givers, rather than just the natural mothers, to apply for the grant (Makiwane \& Udjo, 2006), the CSG has been able to reach much larger numbers of beneficiaries than the SMG could ever have. Accordingly, the introduction of the CSG was celebrated as an important post apartheid milestone towards the attainment of social security and more generally, social justice in South Africa (Ewing, 2004).

However, Lund notes a tendency with all broadly targeted social security benefits: Public opinion and social science research tends to focus "... on negative incentives and the 'perverse' effects of social benefits on such things as household structures, fertility rates, labour seeking 
behaviour and productivity. Much of this [discourse] is strongly economistic, moralistic, valueladen and fairly punitive towards women" (Lund, 2008:56; our brackets). Unsurprisingly then, there has over the past few years developed a public discourse which would suggest that inter alia, the Child Support Grant was unnecessary; that it might indeed be counter-productive in that it contributed to a rise of teen pregnancy; that it was frequently abused by care givers rather than used for the benefit of children; that it stretched scarce government resources; and that the HIV/AIDS pandemic in the country necessitated better support for the care of children (compare for example claims referred to by Lund, 2002, 2007; Makiwane \& Udjo, 2006).

It follows that the Child Support Grant should be regarded as one of the major post-apartheid welfare initiatives towards transforming South African society with a view to reducing the existing depth and scale of poverty and inequality, and to bringing about a more equitable distribution of resources. It forms a constitutive part of the social development agenda embraced in South African welfare (Department of Welfare, 1997; Hölscher, 2008; Midgley, 1995; RSA, 1996; Triegaardt \& Patel, 2005). However, if this is not understood and endorsed by the general public, including social work professionals, students and volunteers, the prospects of further policy initiatives aimed at social development, transformation and redistribution through social security may be undermined (Hölscher, 2008). A lack of understanding of the grant's design and purpose amongst the general public and welfare practitioners in particular may also lead to a range of oppressive consequences, such as for example, the stigmatisation of CSG recipients as "undeserving" poor (Clarke, 1993; Dominelli, 2002; Ife \& Tesoriero, 2006; Lund, 2008; Midgley, 1981; Sewpaul \& Hölscher, 2004). At the same time, such perceptions may reveal deeper underlying issues requiring follow-up research and subsequent social work response, concerning amongst other things, the depth of destruction of South African community and family life.

Just over ten years after the introduction of the Child Support Grant, it seemed therefore appropriate to begin to explore how members of the South African public perceive this grant, to explore how these perceptions speak to the grant's original intentions, how such perceptions fit into broader ideological discourses concerning poverty and social justice, and the implications thereof for the social development agenda in South African welfare.

This study forms part of a research project undertaken by fourth year social work students.

\section{AIM AND OBJECTIVES OF THE STUDY}

The overall aim of the study was to explore the perceptions held by welfare practitioners, namely social workers, social service volunteers and social work students, around the CSG. Research objectives were to explore participants':

- extent of factual knowledge about the CSG;

- understanding of access to the Child Support Grant;

- perceptions of uses and abuses of the grant; and their

- views on how child poverty should ideally be addressed.

\section{RESEARCH METHODS}

A mixed methodologies paradigm was adopted to glean multiple perspectives of the CSG employing qualitative and quantitative approaches, using an exploratory-descriptive design. The qualitative component comprised 25 interviews using a semi-structured interview format 
and five focus group discussions with a total of 43 participants. The quantitative component comprised 72 questionnaires that contained mostly closed and a few open-ended questions.

The study focused on one particular sub-segment of the South African public, that is, social workers, social service volunteers and social work students. Two sampling strategies were adopted for both the qualitative and quantitative components, namely purposive and convenience sampling. Hence, besides participants needing to be aware of the CSG and interested in the study, no further qualifying criteria were employed to secure participation. Seventy two social work students in their first year of study completed the questionnaire in the quantitative study. This sample was selected first, for convenience, and second, it was felt that it would be interesting to ascertain to what extent new social work students were aware of poverty relief and social development efforts, including the facilitation of people's access to social security. Myths, misinformation and knowledge gaps amongst this group could provide guidelines for teaching and learning, and for curriculum development at the entry level of social work studies.

In the qualitative study, 38 social work students in their third year of study, and 15 volunteers at a Durban-based social service organisation consented to participate in focus group discussions. In total, four once-off focus group discussions were held with the students, and one with the volunteers. Although the focus of the study was on perceptions, an unintended occurrence was that a number of student social workers were also grant recipients themselves and were therefore able to share personal experience in addition to generalised perceptions pertaining to the CSG. This may be viewed both as a limitation and as a benefit to the study limiting on the one hand in that results would be more varied given these differing experiences, but beneficial on the other hand since the study was also qualitative, and these views demonstrated in the final analysis that recipients' perceptions and general perceptions converged at many levels, thus adding depth to understanding perceptions of the CSG.

Individual interviews were conducted with nine social workers who participated in the study. Such triangulation of samples enabled us to fulfil the aim of the research, namely, to obtain a range of views on the CSG. As in the case of the social service volunteers, the participants in this sample included people who should have first hand information and experience of the devastating effects of poverty on communities, families and individuals, as well as the potential benefits of social security, including the CSG. They should, for all intents and purposes, be directly involved, or soon become involved, in poverty relief and social development efforts, including the facilitation of people's access to social security. Exploring their views, and how deeply they embrace notions of social justice and of transforming South African society through social welfare and social security, might deepen our understanding of some of the ideological foundations of contemporary South African welfare practice, thereby guiding curriculum design for continuous professional development and the training of social service volunteers.

Data analysis for the qualitative section was thematic content analysis and for the quantitative part, the Microsoft Excel Program was used to calculate frequency and range. Ethical requirements were adhered to with participation being voluntary and confidentiality assured whilst allowing participants the option to withdraw at any time. Ethical clearance was granted by the University of KwaZulu-Natal's Research Ethics Committee to conduct this study. 
One of the limitations of this study was that it was not known how many participants were recipients of the CSG or had direct experiences of trying to access the grant. Still, the responses of such participants contributed to the value and the depth of the investigation.

\section{RESULTS AND DISCUSSION}

In analyzing the data, we noted considerable consistency in the responses obtained across the various samples. We are therefore able to present a combination of the responses while at the same time highlighting the differences that we observed. This section is discussed under subheadings that relate directly to the objectives of the study.

\section{KNOWLEDGE AND UNDERSTANDING OF THE CSG}

Amongst all participants, there was generally a good understanding of qualifying criteria for the CSG and its purpose to supplement family income, to improve care for children and to contribute to alleviating poverty. For example in the quantitative study, $96 \%$ of the 72 respondents knew the qualifying age for receiving the grant, and 42 out of 72 or $58 \%$ of the respondents knew the documentation required for the grant application. At the same time, no conceptual links of these more immediate and concrete policy objectives with welfare paradigms and principles such as social development, social justice, re-distribution of wealth and re-dressing historical injustices were made by any of the participants in any of our samples. Yet, even at this concrete level, some participants were not able to engage on the topic adequately: there were some noteworthy knowledge gaps across all samples in the study. Not all participants were aware of the current amount of the grant, and how this compares to other social security benefits, for example, the old age pension or the disability grant. Other knowledge gaps included a degree of ignorance regarding the application procedures, and the difficulties experienced in accessing the grant. Documents required to successfully access the grant are numerous, and many participants could not identify all of them.

The focus group discussions revealed that several participants either did not know, or did not fully understand the purpose of the "follow-the-child"-principle (Lund, 2008; RSA, 1996), a key feature of the grant. For example, one volunteer claimed that only biological mothers could apply for the CSG and suggested therefore that, "provision must be made for the grandparents, the caregivers' elder sister, as there are others besides mothers that take care of the children". One of the social work students admitted that, "I have no idea because I believe that the grant is for girls", while another asked:

\section{"The grant thing is confusing me now: who actually applies for the CSG, and who does not? Why is it the women all the time who have to apply?"}

The lack of knowledge and understanding displayed here may suggest that the notion of social security forming part and parcel of social development and transformation in South Africa (Department of Social Welfare, 1997; Triegaardt \& Patel, 2005) is not yet broadly embraced by social work students, qualified social workers or social service volunteers. Their responses might indicate instead that they continue to regard the grant system as a separate administrative complex to which referrals can be made but with which continuous updating and engagement is not necessary. This is a matter of concern as welfare practitioners, being at the forefront of service delivery, need to be well informed so as to provide support and guidance to their service users, and be creative in utilising the various aspects of the South African welfare system in order to maximise social work's contribution to social development (Triegaardt \& Patel, 2005). 


\section{PERCEPTIONS CONCERNING ACCESS TO THE CSG}

While there were some gaps in terms of factual knowledge and conceptualisation around the CSG, participants across the study's samples appeared well aware of the barriers that prevent eligible care givers from accessing the grant, and therefore from utilising it in the best interest of the children in their care. Much of this awareness seemed to be rooted in participants' personal experiences, the experiences of immediate others, and hear-say.

Frustrations that were observed to prevent grant access and benefits were similar across all participants, with quantitative measurements pointing to long queues (93\%); corruption/bribery (73\%) and communication problems (58\%). Participants were quick to acknowledge that a major obstacle to access is that many children do not have birth certificates and therefore cannot apply for social grants while others are not even aware that they are entitled to assistance (UNICEF, 2006). Thus, one of the volunteers noted that:

"Parents either do not take the children on time to be registered as most rural babies are born at home, or the mother leaves the baby in the care of her mother... as a result, no one takes the responsibility of registering the child."

In a similar vein, Dlungwana (2007) reports from her study on child-headed households in Durban that those not having proper documents such as birth certificates, identity documents and death certificates ended up with their grant applications not being processed. Similar findings are reported by Mfecane et al. (in Skinner \& Davids, 2006) from their study on orphans and vulnerable children in the Free State. A further issue highlighted by Hall, Leatt and Rosa (2005) and Dlungwana (2007) is that rural people are particularly affected by a lack of personal documentation on account of location, meagre resources and lack of infra structure.

In the qualitative part of this study, it was a perception of bureaucratic inefficiency, malpractice and a sense of disempowerment felt by applicants vis-à-vis social security officers which evoked the most emotional responses from participants. For example, several focus group members reported that their next of kin had been treated "very bad", experienced the grant application process as "very stressful", and found themselves "going back and forth" for three years until they had obtained all the documents required for a successful grant application. One social work student related her personal experience as follows:

"I applied for the grant in the year 2000 ... I had to wait for a period of three years, and after those years I had to re-apply for the grant because when I went back to the social development department they told me that they could not find my details... There was absolutely nothing that I could have done. I didn't ask them any questions because at that time I was so desperate into getting the grant."

These experiences and observations resonate with several aspects of Francie Lund's (2008) reflections on the development and initial implementation of the Child Support Grant. There is firstly the decision taken in the course of 1996 to retain social security as integral part of the South African policy package aimed at responding to child poverty. This was to a considerable extent motivated by the fact that there was a comparatively functional infrastructure in place for the administration of social grants (Lund, 2008). This is by no means to say that the infrastructure which is in place is adequate.

Whatever the existing administrative challenges, the Lund Committee's initial intention was that the CSG should be easily accessible and therefore designed as a universal benefit rather than a means tested grant (Lund, 2008). Yet, this approach did not survive the need to compromise in the face of government's new conservative economic policy, GEAR, and 
concomitant budget capping. Thereafter, it was suggested that there should be a means test, but that this should consist of a "simple, accountable, fast and efficient" system which was more focused on "reaching the poor than screening out the better off, who would in all likelihood not bother to apply for such a modest amount of money" (Lund, 2008:66). Nonetheless, by the time the grant was ready for implementation, the reality looked vastly different:

"What was to have been a simple and accessible grant, became much more complex. The application procedure became exceptionally complicated ... For the CSG, which had been intended to be the most simple, more separate items of information were needed from applicants than for any of the other grants" (Lund, 2008:72-73)

While application procedures have since been simplified again, Lund (2008) contends that this kind of means testing might be indicative of a generally conservative mind-set within government, the public service sector and beyond, which insists on excluding all the "undeserving" poor from public benefits, rather than focusing the system's energies on broadbased poverty relief. Finally, concern about people's difficulties in obtaining birth and death certificates are shared by Lund (2008), who nonetheless asserts the important role the CSG has played since its inception in ensuring that the poor become formally registered as South African citizens and are thus enabled to access a broad range of public benefits as well as participate more effectively in public life.

\section{PERCEPTIONS CONCERNING USES AND MISUSES OF THE CSG}

It was around the research participants' perceptions concerning uses and misuses of the grant where the findings of the study were the most contradictory. While the focus of all participants clearly remained on the best interest of the child, there were numerous, often strongly held perceptions concerning how, once accessed, the grant was used, or abused by its recipients. There was certainly a variety of views. However, negative perceptions dominated.

\section{Productive use of the grant}

General consensus existed that even if the grant was used for other basic necessities such as caring for other family members in the home, this should not be seen as constituting "abuse". The point made was that poverty gave people no option but to "spread" the grant in many directions. As regards potential benefits and uses of the grant, a few participants in the quantitative sample believed that the grant served its intended function (21\%-met basic needs and $25 \%$-alleviates poverty). Focus group and interview participants were able to qualify further benefits/uses such as empowering women, educating children and starting small businesses. For example, one member in the focus group of volunteers reported that:

"The people who are collecting this grant, they make it bigger money. Some of them buy underwear for cheap prices in bulk, then they take it to the rural areas and re-sell the underwear at a profit, so now they have more money."

Other first hand experiences and observations included the following:

"I know ... my aunt ... receives $R 400$ a month ... At the beginning of the year she pays school fees for her two children, and ... all the other months, she is saving the money in the bank ... for them to go to university some day".

"My sister is able to buy little stuff for the child, and it is unlike getting nothing, at least she has a stable source of income that she gets." 
These participants' observations and experiences are supported by evidence from empirical studies: Social grants, specifically old age pensions and the Child Support Grant, indeed have a considerable effect on such indicators of social development and poverty alleviation as food security, school enrolment and reduction of the poverty gap in South Africa (Case \& Ardington, 2004; Case, Hosegood \& Lund, 2005; Poggenpoel \& Olivier, 2005; Taylor Committee, 2002). Nonetheless, the Minister of Social Development, Dr Zola Skweyiya, commented recently "after visits to mostly rural areas ... that even if children were receiving social grants, they continued to live in mud houses, were not attending school, had no access to health facilities, and faced a future devoid of opportunities for development" (cited by Tabane, 2008:6). Such ad-hoc observation can of course not be taken as evidence of the grant's general ineffectiveness. Instead, they might suggest that the Minister of Social Development himself has unrealistic expectations as to what impact a mere R200 (the amount of the grant at the time) on its own could possibly have on the lives of poor people. Either way, it is important to acknowledge the productive use of the CSG by some recipients who ensure future returns via small business initiatives and savings.

\section{Fraud, sex and pregnancy?}

Contrary to the available empirical evidence on the positive effects of the grant, and in spite of the voices of several participants who pointed both to the limited amount of the grant and the good use to which it was nonetheless put, the majority of social workers, students and social service volunteers in this study remained convinced that the CSG was abused. 90,2\% of the participants in the quantitative sample believed the grant was used for "personal gain". In the qualitative samples, alleged misuse of the CSG yielded responses such as:

“A lot of people use skeletons [children that do not in real life exist] to access [the grant]."

"A lot of girls just use the money to buy clothes for their men. They also buy cosmetics for themselves in order to get new boyfriends who will get them pregnant and also leave them at the end of the day. They end up calling their children 'the government's children",

"Many girls buy lingerie with the grant in order to get other men, they end up using the child's money to seduce other guys of the opposite sex. And what I have noticed from these people is that they have children and they forget that these children need food."

"A lot of people use skeletons [children that do not in real life exist] to access [the grant]."

"A lot of girls just use the money to buy clothes for their men. They also buy cosmetics for themselves in order to get new boyfriends who will get them pregnant and also leave them at the end of the day. They end up calling their children 'the government's children'”

"Many girls buy lingerie with the grant in order to get other men, they end up using the child's money to seduce other guys of the opposite sex. And what I have noticed from these people is that they have children and they forget that these children need food."

Similarly, $63 \%$ of participants in the quantitative study saw a direct link between the introduction of the grant and teenage pregnancy. What was not sufficiently explored by those participants in the qualitative samples who made similar claims was, why women and girls would choose to act as it was claimed they did, what this implied about the degree of gender 
inequality and the depth of poverty suffered by ordinary women in South Africa, and how this might best be addressed by social workers without victimising women any further.

Still, most of the empirical studies conducted to date disconfirm a correlation between the Child Support Grant and an increase in pregnancy (Makiwane \& Udjo, 2006). Such a link would indeed be extremely difficult to prove, given the complex socio-economic environment within which the grant is set, including for example, the maturation of the AIDS pandemic, which leads to changing patterns of household expenditure, the CSG's comparatively small amount as compared to the old age and disability grant payments, as well as the fact these three grants are often received in the same households. In fact, fertility levels in South Africa have decreased, not increased, in recent years (Moultrie \& Timaeus, 2003).

Another interesting point made by one of the members of the volunteer focus group was that deeper cultural convictions and practices need to be considered when making claims about the causes of teenage pregnancy.

“They don't like to take contraceptives because she is young, she don't have a baby. When she gets married one day, on the marriage she may not have a baby. Then she will get divorced, because she is not fertile. That is why they start to get pregnant now, so that for the future, I will get a child. If you say to them they must go to the government clinic for treatment, they say, no, first I must have a baby before I am going to take the pill. I can't abstain. If I abstain, my boyfriend will leave me."

As with social problems in general, it would be impossible to identify any one single cause that on its own would sufficiently explain the genesis of this problem. Thus, social work practitioners will have to acknowledge the fact that the introduction of the Child Support Grant - a recent structural change to South African society - interacts with the deeply rooted patriarchal structures of South African society, and multiple layers of women's disempowerment (Jewkes, Levin \& Penn-Kekana, 2002). It can therefore not be singled out as a lone cause of teen pregnancy, as dominant voices in our study suggest. However, in as far as the CSG might indeed motivate young women to fall pregnant in order to access a monthly "income" of R200, it would be an indictment of South African society and the lack of safety, security and social justice it affords some of its most vulnerable members, thus calling for structural social work interventions focused on providing opportunities for the overall development of women (Walker, 2005).

\section{Dependency, laziness and the demise of ubuntu?}

According to the dominant discourses which emerged in all three sets of our data, the CSG encouraged dependency and laziness. One participant alleged thus:

"It encourages some people to leave their children with their parents and then neglect their responsibilities and still receive the grant."

And one social work student claimed that she had overheard:

"Two women in the street sharing a talk on the CSG saying, 'hey you know it is not bad anyway. Mbeki is a source provider. Even if I don't get paid, he is there. I will just leave my child with my in-laws. They take care of my child ... I won't mention that I am getting the grant ... I will just continue eating the money, and I will be fine." "

Several participants related instances of how grandparents were facing the responsibility of caring for their grandchildren while the mothers of the children received the grant and lived elsewhere. Similarly, research by Hall, Leatt and Rosa (2005) revealed that elderly and other 
primary care givers in the community were taken advantage of by mothers and fathers who were not taking responsibility for their children. However, none of those participants who expressed the above concerns seemed to be aware that the CSG can - through a simple administrative procedure - be transferred from an abusing parent to a caring and responsible care giver. This of course is alarming, particularly in relation to the perception held by some participants in our study that avenues for "whistle blowing" did not exist. For if those social workers and volunteers who are directly involved in rendering services to South Africa's marginalised and poor are unaware of the available mechanisms to prevent grant abuse, they will also be directly responsible for having prevented the grant from unfolding to contribute to social development in South Africa.

Finally, an interesting contention made by a number of our participants was that paying the grant eroded ubuntu, which to them denoted the culture of helping and caring without reward. Yet, even though ubuntu signifies a local cultural value, the assertion that social security eroded the moral and social fabric of communities is an one which is as old as the introduction of organised, state-based welfare itself. It is a claim which has been used globally to lobby for cutbacks in social spending generally, and social security spending in particular - one of the more prominent examples being the New Right movement in the United States, Britain and beyond (Sewpaul \& Hölscher, 2004). Thus, our participants' utterances illustrate what a number of scholars have noted before: While reference to local cultural contexts is always possible and in fact necessary to make any welfare debate meaningful, intermittent claims of the socially and morally erosive effects of solidarity and social justice are a global, and a historical phenomenon. As such, they are, much rather than expressions of local cultural conditions, closely related to the world-wide ebbs and flows of economic and social policy paradigms; they are an ideological expression of the group interests of elites the world over (Hölscher, 2008; Sewpaul, 2005; Sewpaul \& Hölscher, 2004).

\section{The "deserving" and the "undeserving" poor}

The sum total then of the perceptions of grant abuse collected in this study corresponds with and extends our findings concerning participants' knowledge and understanding of the grant. That is, inadequately informed about the CSG, not having fully understood its principles, design and role in the overall social development paradigm in South Africa, the majority of our participants displayed an allegiance to a conservative, residual notion of social welfare (Dolgoff, Feldstein \& Skelnik, 1993; Midgley, 1995; Wilensky \& Lebeaux, 1965). Within this mindset, children emerged as the "deserving" poor who were seen to have had no choice concerning their course of life (yet), and who were therefore entitled to help. The mothers on the other hand - fathers did not feature prominently in our participants' discussions - were framed as the people who were actually to be blamed for their children's plight (Ife \& Tesoriero's 2006 discussion of blaming-the-victim discourses on disadvantage). Rather than understanding behaviour as a product of, inter alia, the complex interplay of systemically entrenched patriarchy and poverty, poor women were framed as the culprits in the story of their children's suffering. They are promiscuous, they are irresponsible, lazy and uncaring, they gladly rely on undeserved government handouts, and they use the grant for personal gain and sexual escapades, refusing to put the grant to its intended use.

In the context of such a world view, it is not 350 years of colonialism and poverty that are blamed for the erosion of South Africa's social fabric, of traditional values such as $u b u n t u$, and of a culture of responsibility, pro-activeness and entrepreneurship (compare Ife \& Tesoriero's 2006 discussion of structural disadvantage), it is the Child Support Grant, which had been 
intended as a relatively meagre but broadly accessible means of poverty alleviation and women empowerment (Lund, 2008; RSA, 1996). While it is too early to say whether or not the observations related by our participants actually match an observable reality - further empirical research would be an urgent necessity to follow this up - clearly, those who have been assigned to help children and their caregivers escape the trappings of poverty and patriarchy, regard young mothers as an impediment to poverty alleviation, rather than a group of potential, and "deserving" agents in the long and complex process of poverty alleviation, empowerment and social development.

The history of social work globally has been littered with such punitive, individually focused world views and approaches where social workers and their allied professions label the victims of structural inequality, oppression and powerlessness as the deviant ones who need to be controlled and rehabilitated, instead of critically engaging with the societal structures and practices that may have brought about the so-called deviance in the first place (Chambon, Irving \& Epstein, 1999; Dominelli, 2002; Leonard, 1997; Parton, 1996; Sewpaul \& Hölscher, 2004). However, social work's history is equally speckled with critical discussion and attempts to develop alternative - feminist, structural, radical, and anti-oppressive - approaches to helping (Allen, Pease \& Briskman, 2003; Dominelli, 2002; McLaughlin, 2007; Mullaly, 1997, 2002; Payne, 2005; Pease \& Fook, 1999). These latter contributions may indeed have considerable potential to inform a debate in South African social work on how to utilise the CSG - and other grants - in the country's social development agenda.

\section{VIEWS ON ADDRESSING CHILD POVERTY}

Participants' views on how child poverty should ideally be addressed reflect similar contradictions as do their perceptions of uses and abuses of the CSG. Here however, conservative, residual and punitive suggestions on the one hand and developmentally, or even institutionally oriented contributions on the other appeared much more balanced. Some participants in our study expressed the view that people should make efforts to be selfsupporting instead of being "dependent" on government to support their children. By the same token, several participants asserted that if government invested in job creation, recipients' alleged dependency on grants might as a result decrease. What was missing from such suggestions however, was evidence of knowledge about, in-depth understanding of, and critical reflection on the structural nature and large scale of unemployment in South Africa (Barker, 2003; May, 1998; Terreblanche, 2002), or for that matter, the limited scope and inherent limitations of pubic works, poverty relief and economic development programmes on the other (Hölscher \& Mubangizi, 2007; Lund, 2008; McCord, 2004; Mubangizi, 2008; Skewyiya, 2006).

Thus, the above mentioned themes of "laziness", "dependency" and a "blaming-the-victim" discourses continued to characterise these participants' suggestions on how child poverty should ideally be addressed. One of our interviewees suggested:

"If the government can give handouts only, as most people are using the grant for their needs rather than fulfilling their children's needs, and there is only a few that are so willing to take care for their children. I can say it is those that are extremely desperate for the money."

And another suggestion was: 
"Forcing mothers to buy food and uniforms for their children. This can be done if there are people to monitor this, for example social workers or whatever. Everyone who receives this grant should have a social worker whom they report to after six months."

Ethical concerns and impracticalities of controlling grant recipients' daily spending practices, or of administering voucher systems aside (Lund, 2008), it merits noting that the line dividing control from care in social work has always been a blurred one, and such suggestions were tempered - at times by the same participant within the same contribution - with a range of creative responses concerning social work's potential to work collaboratively with grant recipients, using community work and community development approaches in the interest of social development, women empowerment and poverty relief. Propositions in this regard were, amongst others, the facilitation of community awareness programmes on diverse issues such as teenage pregnancy, family planning, grant access and children's rights, as well as community education programmes on how to utilise the CSG in the best interest of children. A further suggestion was informed by the participant's awareness of the complexity and long-term nature of social development:

"The best way to alleviate child poverty is education. As much as education takes a long time for a person to see the results, but it is one of the many solutions. Child poverty can be best addressed through educating mothers ... The Department [of Social Development] should form allies with the Department of education and form a 20 year plan to alleviate poverty by empowering more women [through education] that is, give more bursaries to women."

Finally, several participants agreed that the CSG should be increased. Their view was that despite receiving the grant, many children were still affected by poverty as the amount was inadequate to address basic needs. In addition, the majority of participants felt that the grant should be extended to children up to the age of eighteen to enable them to complete schooling. Suggestions were also made that additional pay points needed to be established especially in areas far from the city centre. This would save on transport costs for families who were already financially stretched. Accordingly, some social work students and volunteers proposed that social work to should engage communities in social action around issues such as increases in grant payment, or more broad-based and effective government strategies towards poverty relief.

In other words, the fact that our participants embraced simultaneously residual and developmental and institutional notions of welfare, coupled with creative ideas on the various roles and strategies social work could adopt in a national endeavour to address child poverty, suggests the following: There is potential for the mainstreaming of alternative discourses on women, poverty and disadvantage, and for alternative notions of welfare and social work to become more thoroughly embraced over time. A prerequisite for such change in attitude and approach would of course be that relevant research and policy debates continue to be pursued by the profession at large.

\section{CONCLUSIONS AND RECOMMENDATIONS: TOWARDS A CRITICAL SOCIAL SCIENCE FOUNDATION OF SOCIAL WORK PRACTICE}

Amongst the social workers, students and social service volunteers in our study, conservative and residual notions of welfare and at times, misogynistic views of poor and sexually active young women were dominant. Yet, these were balanced with some recognition of the need for a CSG, of the difficulties around implementation of the grant, and of the role of social workers in making it a more effective tool of poverty alleviation, women empowerment and social 
development. At the same time, our participants' responses suggest a dearth of factual and historical knowledge, which, if found to be common, would need to be addressed so as not to undermine the ability of welfare practitioners to base their interventions in critical social analysis. Three specific concerns that emerge from this study's findings are presented in this section, together with our recommendations as to how social work educators and practitioners might best respond.

To begin, participants appeared to generally lack knowledge of the CSG and poverty and instead used stereotypes to interpret personal observations and to make broad generalizations. The knowledge gaps and lack of understanding of the grant, its purpose and role within a developmental welfare paradigm displayed by social workers, students and volunteers point to a need to re-look at student training and the provision of in-service training/continuous education for social workers and volunteers. Such education and training should include information giving and updating of factual knowledge. It should also serve to deepen welfare practitioners' understanding of the historic emergence and structural nature of poverty, unemployment, the disempowerment of women in South Africa, as well as the relationship between social security and social development.

Then, participants across all three samples were concerned about the perceived negative effects of the grant on the "social and moral fibre" of South African society in general, the claim that it "caused" teenage pregnancy in particular, and the alleged abuse of the grant by care givers, specifically young mothers. In spite of these - possibly widespread - perceptions, such effects would be difficult to prove. This is firstly because of the general absence of simple cause-andeffect relations between different social phenomena. Secondly, ten years into the grant's existence, empirical research has already been able to correlate the CSG with several indicators of poverty alleviation and social development. Thirdly, even in as far as our participants' observations might be true, illegal activities tend to elude research. Nonetheless, the contradictory nature of responses gleaned from this study suggest that further - quantitative and qualitative - studies into the actual use and possible abuse of the CSG by its recipients, as well as the reasons behind this are needed. For if it turned out to be true that abuse was significant, its complex, social, historical, cultural and political causes would have to be explored in-depth.

In as far as the said allegations have already been proved to be unfounded, more research might be necessary into how far, and if so why, welfare practitioners persist in holding onto anti-poor and misogynistic stereotypes and prejudices. Such understanding of South African social work's own ideological foundations - and contradictions - might facilitate our moving further away from victim-blaming, demarcationist approaches to welfare (Dominelli, 2002) and controlling, punitive forms of practice. Instead, social work would be enabled to develop, and participate in already existing, focused and targeted strategies of advocacy around poverty and gender inequality, as well as strengths-based, anti-oppressive practice and social justiceoriented, radical and structural responses to these phenomena.

Finally, we had suggested above that the current emergence of neo-liberal economic and residual welfare paradigms and policies is a global phenomenon. In this context, the South African social development and welfare project might well serve as a refreshing alternative to this trend. It might be a helpful point of reference for welfare practitioners and activists in the former welfare states who trying to defend notions of social justice and solidarity against the current tide of conservatism in their countries. At the same time, it might appeal to those in other developing, specifically sub-Saharan, countries who are working to establish developmental welfare states under extremely adverse economic and political conditions. Yet, 
the post-apartheid welfare debate in South Africa has been characterised by contradictory ideological discourses (Hölscher \& Sewpaul, 2006; Hölscher, 2008; Sewpaul \& Hölscher, 2004; Sewpaul \& Hölscher, 2007). These contradictions, if not critiqued, may contribute inadvertently to the entrenchment, rather than replacement of residual notions of welfare. They could consequently serve to prevent social workers, students and social service volunteers from finding their appropriate place and role in the social development landscape of South Africa. For all these reasons, we would do well to explore all possible means and avenues to ensure that the South African developmental welfare project is understood, embraced and actively supported by welfare practitioners.

The Child Support Grant represents an important structural and symbolic point of reference in this debate. And the incongruous nature of our participants' responses concerning a number of aspects of the grant point - importantly - to the potential for change in social service provider's thinking and approaches to practice. For when perceptions of the unintended (negative) effects of the Child Support Grant are balanced with an awareness of its intended (positive) effects, as well as visions of how its effectiveness could be improved in future and why this should be so, then the foundations are laid for an invigorating debate on the future direction of welfare policy in South Africa. A pre-requisite for this to happen is that social workers, students, volunteers, and of course policy makers in the welfare sector engage critically with their own ideological leanings, perceptions and prejudices vis-à-vis empirical research findings.

\section{REFERENCES}

ALLEN, J., PEASE, B. \& BRISKMAN, L. (eds) 2003. Critical social work: an introduction to theories and practices. Australia: Allen \& Unwin.

BARKER, F 2003. The South African labour markets $\left(4^{\text {th }}\right.$ ed). Pretoria: Van Schaik Publishers.

BARRY, B. 2005. Why social justice matters. Cambridge: Polity Press.

BRANDON, M. \& PATHER, S. 2007. Eight million on child support. The Times, November, 13.

CASE, A. \& ARDINGTON, C. 2004. The impact of parental death on school enrolment and achievement: longitudial evidence from South Africa. CSSR Working Paper No. 97. Cape Town: University of Cape Town.

CASE, A., HOSEGOOD, V. \& LUND, F. 2005. The reach and impact of the Child Support Grant in South Africa: evidence from KwaZulu-Natal. Development Southern Africa, 22(4):467-482.

CASSIEM, S., PERRY, H., SADAN, M. \& STREAK, J. 2000. Child poverty and the budget. Cape Town: Idasa.

CHAMBON, A.S., IRVING, A. \& EPSTEIN, L. (eds) 1999. Reading Foucault for social work. New York: Columbia University Press.

CLARKE, J. 1993. The comfort of strangers: social work in context. In: CLARKE, J. (ed) A crisis in care? Challenges to social work. London, Newbury Park, New Delhi: Sage Publications.

DEPARTMENT OF WELFARE. 1997 White Paper for Social Welfare. Available: www.gov.za/whitepaper/1997. [Accessed: 10/10/2003]. 
DLUNGWANA, N.E. 2007. The experiences of children who are heads of households in Hammarsdale. Durban: University of KwaZulu-Natal. (Unpublished MA Thesis)

DOLGOFF, R., FELDSTEIN, D. \& SKELNIK, L. 1993. Understanding social welfare $\left(3^{\text {rd }}\right.$ ed). New York \& London: Longman.

DOMINELLI, L. 2002. Anti-oppressive social work theory and practice. Houndmills, Basingstoke \& Hampshire: Palgrave MacMillan.

EWING, D. 2004. Constitution of South Africa. Children First, (8):57-58.

HALL, K., LEATT, A. \& ROSA, S. 2005. Does the 'means' justify the end? Targeting the Child Support Grant. In: LEATT, A. \& ROSA, S. (eds) Towards a means to live: targeting poverty alleviation to make children's rights real. Cape Town: Children's Institute.

HÖLSCHER, D. \& SEWPAUL, V. 2006. Ethics as a site of resistance: the tension between social control and critical reflection. In: HALL, N. (ed) Social work: making a world of difference. Social work around the world IV in the year of IFSW's 50 ${ }^{\text {th }}$ Jubilee. $^{\circ}$ International Federation of Social Workers and Fafo.

HÖLSCHER, D. \& MUBANGIZI, B. 2007. The experience of poverty in South Africa: Implications for social work and community development practice. In: REKHLAU, C. \& LUTZ, R. (eds) Sozialarbeit des Südens. Band 2 - Schwerpunkt Afrika. Oldenburg: Paulo Freire Verlag.

HÖLSCHER, D. 2008. The Emperor's new clothes: the attempted transition to developmental social welfare and social work in post-apartheid South Africa. International Journal of Social Welfare, 17(2):114-123.

IFE, J. \& TESORIERO, F. 2006. Community development: community-based alternatives in an age of globalization $\left(3^{\text {rd }} \mathrm{ed}\right)$. French Forest: Pearson Education.

JEWKES, R., LEVIN, J. \& PENN-KEKANA, L. 2002. Risk factors for domestic violence: findings from a South African cross-sectional study. Social Science \& Medicine, 55(8):16031617.

LANDMAN, J.P., BHORAT, H., VAN DER BERG, S. \& VAN AARDT, C. 2003. Breaking the grip of poverty and inequality in South African 2004-2014: current issues and future policy options. Available: http://www.sarpn.org.za. [Accessed: 14/05/2007].

LEE, J.A. 2001. The empowerment approach to social work practice. Building the beloved community. New York: Columbia University Press.

LEONARD, P. 1997. Postmodern welfare. Reconstructing an emancipatory project. London, Thousand Oaks, New Delhi: Sage Publications.

LUND, F. 2002. Consensus \& contestation: the policy for child support in South Africa. Draft Monograph, School of Development Studies, University of Natal.

LUND, F. 2007. Lecture: the child support grant. Unpublished address to University of KwaZulu-Natal Level 4 Social Work Students. March.

LUND, F. 2008. Changing social policy: the Child Support Grant in South Africa. Cape Town: HSRC Press. 
MAKIWANE, M \& UDJO, E 2006. Is the Child Support Grant associated with the increase of teenage fertility in South Africa: evidence from National Service and Administrative Data. Pretoria: Human Resource Council.

MANUEL, T.A. 2007. Budget Speech 2007. Available: http://www.info.gov.za. [Accessed: 25/05/2007].

MANUEL, T.A. 2008. Budget Speech 2008. Available: www.businesspartners.co.za/ budgetspeech2008.pdf. [Accessed: 10/04/2008].

MAY, J. 1998. Poverty and Inequality in South Africa: report prepared for the Office of the Executive Deputy President and the Inter-Ministerial Committee for Poverty and Inequality. Summary Report. Available: http://www.welfare.gov.za/Documents/1998/ Pov.htm. [Accessed: 29/05/2007].

McCORD, A. 2004. Public works as a component of social protection in South Africa. Available: www.big.org.za. [Accessed: 28/11/2007].

McLAUGHLIN, H. 2007. Understanding social work research. London: Sage Publications. MFECANE, S., SKINNER, D., MDWABA, T., MANDIVEVENYI, C. \& NTJANTJA, N. 2006. A situational analysis of OVC services in the Kopanong municipality, Free State. In: SKINNER, D. \& DAVIDS, A. (eds) A situational analysis of orphans and vulnerable children in four districts of South Africa. Cape Town: HSRC: 31-46.

MIDGLEY, J. 1981. Professional imperialism: social work in the Third World. London: Heinemann Educational Books.

MIDGLEY, J. 1995. Social development. The developmental perspective in social welfare. London: Sage Publications.

MOULTRIE, T.A. \& TIMAEUS, I.M. 2003. South African fertility decline: evidence from two censuses and a Demographic and Health Survey. Population Studies, 57(3):265-283.

MUBANGIZI, B.C. 2008. Responses to poverty in post-apartheid South Africa: some reflections. International Journal of Social Welfare, 17(2):174-181.

MULLALY, R.P. 1997. Structural social work: ideology, theory and practice. Oxford: Oxford University Press.

MULLALY, R.P. 2002. Challenging oppression: a critical social work approach. Oxford: Oxford University Press.

PARTON, N. 1996. Social theory, social change and social work: an introduction. In: PARTON, N. (ed) Social theory, social change and social work. London, New York: Routledge.

PAYNE, M. 2005. Modern social work theory ( $3^{\text {rd }}$ ed). New York: Palgrave MacMillan.

PEASE, B. \& FOOK, J. (eds) 1999. Transforming social work practice: postmodern critical perspectives. London \& New York: Routledge.

POGGENPOEL, S. \& OLIVER, L. 2005. Investigating the implications of ten years of democracy for women: the role of the Department of Social Development. Available: http://www.idasa.org.za. [Accessed: 28/11/2006].

RSA (REPUBLIC OF SOUTH AFRICA). 1996. Report of the Lund Committee on Child and Family Support. Pretoria: Government Printer. 
SEWPAUL, V. 2005. A structural social justice approach to family policy: a critique of the draft South African Family Policy. Social Work/Maatskaplike Werk, 41(4):310-322.

SEWPAUL, V. \& HÖLSCHER, D. 2004. Social work in times of neo-liberalism: a postmodern discourse. Pretoria: Van Schaik.

SEWPAUL, V. \& HÖLSCHER, D. 2007. Against the odds: community-based interventions for children in difficult circumstances in post-apartheid South Africa. In: DOMINELLI, L. (ed) Revitalising communities in a globalising world. Hampshire: Ashgate.

SKWEYIYA, Z. 2006. Media statement: minister to launch project aimed at reducing dependency on social grants. Available: http://www.gov.za. [Accessed: 16/05/2007].

TABANE, R. 2008. A(nother) war on poverty. Mail and Guardian, 15-21 February, 6.

TAYLOR COMMITTEE. 2002. Transforming the present - protecting the future. Draft Consolidated Report of the Committee of Inquiry into a Comprehensive System of Social Security for South Africa. Pretoria: National Department of Social Development.

TERREBLANCHE, S. 2002. A history of inequality in South Africa 1652-2002. Jointly published by University of Natal Press (Scottsville) and KMM Review Publishing (Sandton).

TRIEGAARDT, J. \& PATEL, L. 2005. Social security. In: PATEL, L. Social welfare \& social development in South Africa. Cape Town: Oxford Southern Africa.

UNDP. 2004. South African Human Development Report 2003. Pretoria: United Nations Development Programme and Oxford University Press.

UNICEF. 2006. Saving children, enhancing lives: combating HIV and AIDS in South Africa. Pretoria: UNICEF.

WALKER, L. 2005. Negotiating the boundaries of masculinity in post-apartheid South Africa. In: REID, G. \& WALKER, L. Men behaving differently. Cape Town: Double Storey Books: 161-182.

WILENSKY, H.L. \& LEBEAUX, C.N. 1965. Industrial society and social welfare. New York \& London: The Free Press \& Collier-MacMillan.

Acknowledgements: The authors would like to acknowledge the following students who were involved in the research project:

C Weir-Smith, F Al Razak, I Naicker, L Ngcobo, M Ndlovu, M Yandisa, N Chanderman, N Masinga, N Ncwane, N P Ndaba, N P Ndaba, N Shabane, P Mncwabe, P Mnqayi, P Mpisi, S Chinsamy, TN Nkomo

Ms Dorothee Hölscher, Lecturer, School of Social Work and Community Development, University of KwaZulu-Natal: Howard College Campus, Durban, South Africa.

Prof Madhubala Ishver Kasiram, School of Social Work and Community Development, University of KwaZulu-Natal: Howard College Campus, Durban, South Africa.

Dr Reshma Sathiparsad, Senior Lecturer, School of Social Work and Community Development, University of KwaZulu-Natal: Howard College Campus, Durban, South Africa. 